\title{
Relevant opplæring i yrkesopplæringens første år: Elevers erfaringer med yrkesrelevant opplæring
}

\author{
(Relevant training in the first year of vocational training: \\ Pupils' experience with vocational training) \\ Åse Nedrebø Bruvik ${ }^{1}$ \& Grete Haaland \\ OsloMet - Storbyuniversitetet, Norge (ase.bruvik@oslomet.no)
}

\begin{abstract}
During the last years, vocational education in Norway has been organised through eight different educational programmes. Each programme makes the basic year for many different professions, students may be heading for. The national regulations for Norwegian vocational education and training describe a clear intention of professional relevance for each student and competence development through democratic participation. The aim of this research was to investigate how the basic year in vocational programmes works, related to these intentions from a student perspective. This study provides both qualitative and quantitative results.

Despite the fact that most of the students, before or during the first year, have decided on their future profession, the survey shows that the basic year in Norwegian vocational education is not, or only partially relevant to their vocational plans.

The students find that their possibilities to influence in deciding their learning tasks and the educational content is minimal. Interpretation and understanding of curriculum, learning assignments and educational content are decided by the teachers or others, not the students.
\end{abstract}

Keywords: vocational relevance, vocational interests, vocational plans, student influence, student participation 


\section{Innledning}

Både norsk og internasjonal forskning fremhever betydningen av en yrkesrelevant opplæring. Mange peker på nødvendigheten av å differensiere undervisningen, slik at den kan tilpasses den enkelte elevs yrkesplaner eller yrkesinteresser (Dahlback, 2019; Dahlback, Hansen, Haaland \& Sylte, 2011; Dahlback, Olstad, Sylte \& Wolden, 2018, 2019; Hansen, 2017; Kember, Ho \& Hong, 2008; Wheelahan \& Moodie, 2010). Kompetansen elevene skal utvikle er i den norske læreplanen utformet som kompetansemål. Disse er åpne og generelle, slik at de kan tolkes mot forskjellige yrker. Gjennom ulike metoder og tilnærminger gir dette handlingsrom for å individualisere innholdet og læringsarbeidet tilpasset elevens læringsbehov (Utdanningsdirektoratet, 2006). Forskning viser at elever har forventninger til at innholdet $\mathrm{i}$ utdannelsen er relevant for deres fremtidige yrkeskarriere (Bødker-Lund, Hansen, Haaland \& Vagle, 2017; Kember et al., 2008). Det pekes blant annet på at lærerne må styrke undervisningspraksisen og forankringen til arbeidslivet for å ivareta mangfoldet og utdanningskvaliteten i yrkes- og profesjonsutdanningene (Billett, 2014; Hiim, 2013; Jørgensen, Olsen \& Thunqvist, 2018).

Yrkesopplæringen i Norge er organisert i åtte utdanningsprogrammer. Hovedmodellen er to år i skole og to års læretid i bedrift. De empiriske eksemplene i artikkelen er fra første året i skole (Vg1), og er begrenset til å omfatte utdanningsprogrammene Elektro (EL), Bygg- og anleggsteknikk (BA), Teknikk og industriell produksjon (TIP), Design og håndverk (DH) og Helse- og oppvekstfag (HO). Det er mange og til dels svært ulike yrker i ett og samme utdanningsprogram. Vg1 kan være første del av opplæringen for inntil cirka 70 yrker som fører fram til fag- eller svennebrev (Hansen \& Haaland, 2015). Dette kan skape utfordringer for Vg1-lærere. De skal, i tråd med læreplanverket, legge til rette for og lede en tilpasset og yrkesrelevant opplæring for elever i samme klasse med ulike utdannings- og yrkesplaner.

Både norsk og internasjonal forskning viser at yrkesretting, elevmedvirkning og relevans har stor betydning for elevenes motivasjon første året (Vg1). Dette er felles for mange yrker (Bødtker-Lund, Hansen, Haaland \& Vagle, 2017; Dahlback et al., 2011; Dahlback, 2019; Jørgensen et al., 2018; Kember et al., 2008).

Læreres bruk av handlingsrommet i læreplanen gir, ved siden av elevenes erfaringer og læringsbehov, grunnlag for å drøfte hvordan kvaliteten i framtidens yrkesopplæring kan endres og videreutvikles. Funnene kan være et nyttig innspill i den pågående endringsprosessen mot ny reform i Norsk yrkesopplæring, som iverksettes høsten 2020 (Kunnskapsdepartementet [KD] 2018). Hensikten med denne undersøkelsen er ikke å gjennomføre en læreplananalyse i utdanningsprogrammene. Målet er å synliggjøre hvordan handlingsrommet i planene brukes for å gi en yrkesrelevant opplæring i Vg1 - sett fra et elevperspektiv. Artikkelens problemstilling blir ut fra dette: Hvordan brukes handlingsrommet $i$ 
Åse Nedrebø Bruvik \& Grete Haaland

læreplanene som grunnlag for en yrkesrelevant opplæring for elever med ulike yrkesinteresser?

Vi har valgt å ta utgangspunkt i to ulike perspektiver fra Goodlad's læreplanteori. Intensjonene for yrkesrelevant opplæring beskrives i NOU-er og Stortingsmeldinger, og gir et bilde av den intenderte læreplanen og et utenfraperspektiv. Studien av elevenes erfarte yrkesrelevans gjennom en spørreundersøkelse gir oss et innenfraperspektiv og innsikt $\mathrm{i}$ hvordan handlingsrommet i læreplanene faktisk brukes (Goodlad, 1979).

\section{Sentrale føringer i norsk yrkesopplæring}

Fra innføringen av LK06 (2006) har det gjennom nasjonale føringer vært fokus på relevans, og intensjonen om at elever skal ha innflytelse og medvirkning på eget læringsarbeid. Målet er å sikre opplevelse av yrkesrelevans i forhold til elevens yrkesplaner eller yrkesinteresser. Dette er gjennomgående målsetting i hele opplæringsløpet, og har vært det i mange år (KD, 2006, 2013, 2016, 2017a, 2017b; Nasjonal kompetansepolitisk strategi 2017-2021, 2017; NOU 2018:2; NOU 2015:8; Utdannings- og forskningsdepartementet, 2004). Ved å bruke handlingsrommet i læreplanene kan innholdet tolkes i forhold til elevenes yrkesinteresser. Dette kan sikre yrkesrelevans for elever med ulike yrkesinteresser i tråd med de nasjonale føringene (Bødker-Lund et al., 2017). Utdannings- og forskningsdepartementet (2004) som danner grunnlaget for dagens yrkesopplæring, omtales betydningen av relevante utfordringer for elevenes læring og utvikling av yrkeskompetanse. Dette har senere blitt ytterligere understreket i KD $(2013,2016,2017 b)$ og NOU 2015:8, som ligger til grunn for den nye reformen Fagfornyingen, som iverksettes høsten 2020. Handlingsrommet i de nasjonale føringene kan forstås som muligheten lærere har til å tolke kompetansemålene. Slik kan lærerne legge til rette for en yrkesdidaktisk opplæring hvor elevene erfarer at det de lærer i skolen er nyttig og aktuelt for egne yrkesplaner eller yrkesinteresser. Evalueringen av Kunnskapsløftet (LK06) viser at det er ulike tolkning blant lærere av hvordan handlingsrommet $\mathrm{i}$ læreplanene kan nyttes for å oppnå en yrkesrelevant opplæring (Vibe, Wigum Frøseth, Hovdhagen \& Markussen, 2012).

\section{Sentral forskning}

I en internasjonal studie ble studenter fra ni ulike fagområder på tre forskjellige universiteter i Hong Kong intervjuet for å karakterisere hva som påvirket undervisning og læringsmiljøer. Studien, som er utført på et høyere nivå innen utdanning, er interessant. Den har, slik vi ser det, overføringsverdi til videregående opplæring. Studien hevder at de viktigste virkemidlene for å motivere elevene til å lære er å etablere relevans. Etablering av relevans var den mest fremtredende og oftest siterte studentresponsen. Det ble hevdet at dersom læringen skulle gi 
mening, måtte det etableres en sammenheng mellom skolen og elevens hverdag (Kember et al., 2008). Studien viser også at en nøkkelfaktor er å gi elevene handlingsrom for å konstruere sin egen relevans ved å relatere innholdet til sin kontekst. Dette kan i yrkesfaglig utdanning handle om at den enkelte elev knytter læringsinnholdet til sitt yrkesvalg eller sin yrkesinteresse (Kember et al., 2008). En norsk studie viser det samme for elever i videregående skole, yrkesfag, nemlig at demokratisk medvirkning bidrar til en meningsfull opplæring. Bakgrunnen er at elevene deltar i valg av læringsoppgaver og arbeidsmåter slik at innholdet blir yrkesrelevant for den enkelte elev (Hansen \& Haaland, 2015). På tross av fokuset på yrkesrelevans og tilpasset opplæring i styrings- og intensjonsdokumenter og læreplanenes store handlingsrom, erfarer mange elever opplæringen som lite relevant og meningsfull (Bødtker-Lund, Hansen, Haaland \& Vagle, 2017; Dahlback et al., 2011, 2018, 2019; Hansen, 2017; Hansen \& Haaland, 2015; Hiim, 2013; Hovland, 2015).

En australsk studie understreker viktigheten av at lærerne holder seg oppdatert i eget yrke for å kunne undervise i hele yrkets bredde. Studien viser til behovet for bredde i eget fag, og er derfor interessant i denne sammenheng, hvor bredde omhandler yrkene i ett og samme utdanningsprogram. Dette innebærer forventninger til at lærer tilrettelegger for en relevant undervisning til et bredt spekter av yrker i utdanningsprogrammet. Studien peker på et behov for delt ansvar, og et tett samarbeid mellom skole og bedrift i utviklingen av en helhetlig og aktuell yrkesopplæring (Wheelahan \& Moodie, 2010, s. 16).

\section{Yrkesrelevant opplæring - fra intensjon til realitet}

Noen av utfordringene i de brede utdanningsprogrammene er knyttet til hvordan lærerne kan tilpasse faglig innhold og arbeidsmåter til alle elevene i en klasse med mange, og til dels ulike yrkesinteresser. Undervisningen er basert på lærerens kunnskaps- og læringssyn og på deres tolkning av innholdet i læreplanene. Dette indikerer hvordan læreplanen oppfattes, tolkes og brukes som styringsdokument. Formidler læreren kompetansemål og lærestoff på generell basis, eller "speiler" opplæringen behovet for kompetanse i de yrkene elevene utdanner seg til, og i samfunnet? Det siste betyr at tolkningen og forståelsen av de fagspesifikke læreplanene må være i kontinuerlig utvikling, i tråd med de intenderte læreplanene, endringer i yrkene og samfunnets kompetansebehov (Goodlad, 1979; $\mathrm{KD}, 2016)$. I en slik forståelse av yrkesrelevant opplæring relateres utdanningsinnholdet, undervisningen og vurderingen til elevenes yrkesplan og forankres $i$ arbeidslivets og samfunnets behov for høyt kvalifiserte fagfolk (Hiim, 2013). I følge Ryan og Deci (2000) har menneskene et iboende driv mot å søke utfordringer for eksempel knyttet til å lære et yrke. Videre peker de på at motivasjon som drivkraft for læring ikke handler om at læreren skal motivere eleven, men at han/hun må tilrettelegge for medvirkning. Slik kan eleven utvikle autonomi og 
involveres med innflytelse på valg av eget læringsarbeid (Ryan \& Deci, 2000, s. $54)$.

Denne studien har utgangspunkt i et pragmatisk kunnskapsyn på læring, som legger vekt på at kunnskapen ikke primært overføres og formidles gjennom generell kunnskap, men utvikles gjennom erfaring, demokratisk medvirkning, samarbeid og kommunikasjon i et aktivt læringsmiljø (Dewey, 1966; Hansen \& Haaland, 2015; Hiim, 2013). Ifølge Dewey krever slik opplæring et positivt, pragmatisk og kritisk kunnskapssyn, demokratisk ledelse fra lærerens side, og demokratisk medvirkning og involvering fra elevenes side. Dette læringssynet støttes i NOU 2015:8 og i KD (2016). Her hevdes det at dersom opplæringen skal gi forståelse for sammenheng mellom opplæringens innhold og elevenes fremtidige yrke, kan dette gjøres gjennom å styrke elevenes motivasjon. Det betyr at innholdet i opplæringen må tuftes på en tilnærming hvor eleven har mulighet å tilpasse læringsoppdraget og forankre læringsarbeidet i egne yrkesinteresser eller -planer (Hiim, 2013; Ryan \& Deci, 2000, 2017).

\section{Metode og analyse}

For å få innsikt i hvordan handlingsrommet i læreplanene brukes med det målet å gjøre opplæringen yrkesrelevant for den enkelte elev, gjennomførte vi en spørreundersøkelse blant 203 elever. Målet var å få innsikt i elevenes erfaringer med hvordan innholdet i Vg1 ble tilpasset deres yrkesplan eller yrkesinteresser.

Undersøkelsen viser innledningsvis hvor mange elever som har bestemt seg for hvilket yrke de ønsker å utdanne seg til, og om yrkesvalget ble tatt før eller i løpet av Vg1. Spørreskjemaet inneholdt spørsmål med svaralternativer etterfulgt av et åpent kommentarfelt for utdyping med egne ord, noe som gir en kombinasjon av kvantitative og kvalitative data. Videre viser studien elevenes innflytelse på innhold og arbeidsmåter i lys av egne yrkesplaner/interesser. Den viser også hvor lang tid den enkelte elev har arbeidet med oppgaver innen sitt yrke/sin interesse i de felles programfagene (FP) og i faget Yrkesfaglig fordypning (YFF). Det viser også om de har arbeidet med ett eller flere yrker i YFF. I siste delen viser undersøkelsen hvilke produkter og arbeidsoppgaver elevene har jobbet med. Disse blir sett i lys av den enkeltes utdannings- og yrkesplan, og hvilke forventninger elevene hadde til Vg1. Funnene knyttes til om elevene kom inn på sitt førstevalg, og om de hadde bestemt seg for hva de ønsker å utdanne seg til da de begynte i Vg1. Den samlede empirien belyser elevenes ulike erfaringer av samme virkelighet, og bidrar til et nyansert og mangfoldig perspektiv på hvordan læreplanenes handlingsrom brukes i opplæringen.

Valget av informanter er begrunnet $i$ at de var elever ved skoler som representerte de utvalgte utdanningsprogrammene. Elevene var fordelt på fem yrkesfaglige utdanningsprogram. 33 elever var fra BA, 42 elever fra EL, 48 elever fra TIP, 42 elever fra DH og 38 elever fra HO. Bakgrunnen for valg av utdannings- 
program var at de innholdsmessig er ulike, men like på den måten at alle er utgangspunktet for mange yrker. En pilotstudie ble gjennomført i forkant av spørreundersøkelsen for å sikre at spørsmålene var formulert på en slik måte at informantene forstod betydningen av dem. I analysedelen jobbet vi to forskere sammen for å sikre perspektivering og kvalitetssikring av analysen. Populasjonen begrenser seg til fire skoler fordelt på to fylker. Det betyr at resultatet ikke nødvendigvis ville blitt det samme $i$ andre deler av landet.

Analysemodellen som ble brukt i bearbeiding av empirien fra undersøkelsen er basert på Malteruds (2017) modell for systematiske tekstkodensering. Modellen er en pragmatisk metode for analyse av kvalitative data. Analysen er egnet for utvikling av beskrivelser og delvis for begrepsavklaring, og består av fire trinn. Elevenes kvalitative beskrivelser gir grunnlag for å tolke deres subjektive perspektiver og erfaringer for hvordan handlingsrommet brukes. For å holde fokus på problemstillingen var spørsmålene i spørreundersøkelsen utgangspunkt for den første kategoriseringen, utformet i forkant av gjennomføringen. Underveis i analysearbeidet, basert på elevenes svar, ble analysekategoriene videreutviklet.

Allerede i første trinn av analysen, som omhandlet behandling av rådata, startet kodingen (Malterud, 2017). På spørsmål om hvilke produkter og arbeidsoppgaver eleven hadde arbeidet med, ble svar som "det vi fikk beskjed om fra lærer", eller hvor elevene ramset opp navn på mange ulike oppgaver, verktøy og materialer plassert i kodene: "ulike oppgaver", "verktøy og materialer", "litt om alt" og "lærerstyrt". Svar som "det som var relevant for oppgaven" eller "det jeg hadde lyst til", ble lagt inn i koden: "i henhold til yrkesplan eller interesser".

Trinn to omhandlet en systematisk gjennomgang av resultatet fra trinn en. I denne delen av analysen ble for eksempel beskrivelser av verktøy- og materialbruk sett i sammenheng med elevenes yrkesplaner eller -interesser. Elevenes beskrivelser ble her bearbeidet og kodet i flere omganger før de ble lagt inn under kategorier $i$ analysens tredje trinn. Her blir analysen oppsummert i en oversikt som viser hvordan arbeidsoppgaver og bruk av verktøy og materialer i Vg1 samsvarte med reelle arbeidsoppgaver, verktøy og materialer i yrkene elevene hadde bestemt seg for å utdanne seg til, eller var interessert i. Videre ble dataene i fjerde trinn abstrahert, identifisert, kodet og kondensert inn i overordnede kategorier som representerer mangfoldet i elevenes beskrivelser. For å belyse i hvilken grad elevene opplever at handlingsrommet blir brukt for å tilrettelegge for en yrkesrelevant opplæring, var noen av hovedspørsmålene utformet med tilleggsspørsmål. Disse konkretiserer elevenes svar slik at de kunne analyseres og tolkes i forhold til hverandre. 


\section{Resultater og diskusjon}

Resultater av analysen presenteres tilknyttet spørsmålene i undersøkelsen i form av beskrivende og forklarende tekst, samt to tabeller. Til slutt diskuterer vi hvordan handlingsrommet i læreplanene brukes for å sikre en yrkesrelevant opplæring for elever i Vg1 med ulike yrkesinteresser.

Det kan ha stor betydning for elevenes motivasjon og opplevelsen av relevans om de er kommet inn på første-, andre- eller tredjevalget sitt. Derfor ble følgende spørsmål stilt; Hvilket utdanningsprogram var førstevalget ditt da du søkte videregående skole? Når bestemte du deg eventuelt for hoilket yrke du ville utdanne deg til? Hvordan handlingsrommet blir brukt for å legge til rette en yrkesrelevant opplæring for elever med svært ulike behov kan ha konsekvenser for hvordan eleven opplever nytteverdien av det han/hun lærer.

Resultatene viser at på EL er alle elevene kommet inn på sitt førstevalg, mens på DH, som hadde størst andel av andre-/tredjevalgs-elever, var 36 av 42 elever $(86 \%)$ kommet inn på sitt førstevalg. En av årsakene til at EL har 100\% førstevalgelever kan være at utdanningsprogrammet har flere søkere enn plasser. Dette er interessant når resultatene viser at EL er det utdanningsprogrammet hvor færrest elever hadde bestemt seg (før, eller i løpet av Vg1) for hvilket yrke de ville utdanne seg til (71\%). På DH, som hadde høyest antall andre- og tredjevalgselever, viser resultatene at $74 \%$ av elevene hadde bestemte seg før eller i løpet av Vg1. Dette kan muligens ses i sammenheng med at elever som har hatt DH som førstevalg ikke har hatt en klar yrkesplan eller yrkesinteresse innenfor yrkene i utdanningsprogrammet, noe kommentarer kan tyde på. For eksempel: "Jeg søkte DH fordi jeg er lei skole og liker kunst og håndverk og siden jeg ikke hadde klart tre år med bare skole så vil jeg gå på noe som interesserer meg." Kommentaren kan forstås som at eleven ikke har bestemt seg for et yrke innen DH, men ønsker en utdanning der det er muligheter for å arbeide praktisk. Når en ser på utdanningsprogrammene i undersøkelsen samlet sett, viser den at 85 av 203 elever hadde bestemt seg for yrke i løpet av Vg1, mens 99 elever hadde bestemt seg før Vg1. Den høye andelen av elever som har bestemt seg for yrke før Vg1 kan indikere at mange elever har en forventning om og behov for yrkesrelevant opplæring. Den store andelen av elever som hadde bestemt seg for et yrke før Vg1, kan også indikere at elever i ungdomsskolen har behov for å bli kjent med yrkene i utdanningsprogrammene på et tidlig tidspunkt for å sikre at utdanningsvalget er i samsvar med deres forventninger av oppgaver i det spesifikk yrket.

Hensikten med spørsmålet om forventninger til Vg1 var å legge grunnlag for å tolke elevenes erfaringer med innhold og arbeidsmåter i Vg1. Manglende samsvar mellom forventninger og innhold kan ha betydning for motivasjonen, behovet for og opplevelsen av relevans i opplæringen. Dersom elevene ikke har forventninger til opplæringen, har de kanskje heller ikke behov for at opplæringen skal være relevant for et spesielt yrke - i motsetning til om de har store 
forventninger og et klart yrkesmål. Her viser dataene at elevene i alle utdanningsprogrammene har størst forventninger til det faglige innholdet. Funn som skiller seg ut her er forventninger om å jobbe praktisk. På DH og HO er det bare cirka $3 \%$ som har forventninger om å arbeide praktisk, mens det på BA, som hadde høyest forventninger, var kun $15 \%$ som hadde forventninger om praktisk jobbing. Det er interessant at faglige forventninger skiller seg ut med høyest andel, mens forventningene til praksis er forholdsvis lave. Dette kan ha ulike årsaker. Det kan tenkes at faglige forventninger knyttes opp mot behovet for en yrkesrelevant opplæring, mens praktisk jobbing muligens oppleves som en naturlig del av yrkesopplæringen. Elever som hadde bestemt seg for et bestemt yrke- de ønsket å utdanne seg til hadde høyest forventninger til det faglige innholdet. De uttrykte behov for at handlingsrommet i læreplanene ble brukt slik at deres læringsarbeid kunne relateres til deres yrkesvalg i større grad enn hos de som ikke hadde bestemt seg for et spesifikk yrke.

Undersøkelsen viser at bare $16 \%$ av elevene hadde størst forventninger til sosiale forhold. Her var det lite variasjon mellom utdanningsprogrammene. At det er så få elever som har sosiale forventninger, kan indikere at de faglige forventningene på Vg1 er viktige for elever som kommer rett fra ungdomsskolen og er opptatt av forandring, fremtidig yrke og arbeidsliv. Beskrivende svar som "mer ansvar og lære om ting jeg får bruk for i jobb" kan indikere elevers forventninger om å medvirke til en yrkesrelevant opplæring på Vg1. 16\% sier at de har ingen forventninger til opplæringen, noe som kan ha sammenheng med at de har kommet inn på sitt andre- eller tredjevalg, og dermed ikke regner med å få lære noe de er interessert i eller får bruk for i et fremtidig yrke. Hensikten med spørsmålene Synes du at du hadde nok innflytelse/medvirkning på hva du skulle gjøre? og Hva skulle du eventuelt ønske å ha mer innflytelse på? var å finne ut hvilke behov elevene hadde for innflytelse på eget læringsarbeid. Behovet for innflytelse ble sett i sammenheng med vår tolkning av deres reelle innflytelse, gjennom deres beskrivelse av hva de hadde gjort av læringsarbeid, hvilke materialer, verktøy og produkter de hadde brukt, og hvilke yrker de eventuelt var interessert i eller hadde bestemt seg for å utdanne seg til.

Her viser resultatene at DH er det utdanningsprogrammet hvor færrest elever opplever å ha nok innflytelse/medvirkning på eget læringsarbeid (33\%), mens EL og TIP har størst andel av elever som mener de har nok innflytelse på eget læringsarbeid (70\%). Spørsmålet var utformet med tre alternative svar som: Ja, Nei, Vet ikke, og et åpent svaralternativ som gav muligheten for utdyping om hva eleven skulle ønske å ha mer innflytelse på. En elev sier for eksempel at "leksene er så unødvendige at jeg blir umotivert av de", mens en annen sier at han ønsker "mer frihet og ikke bare høre på noen som snakker, jeg ønsker å jobbe med stoffet slik at jeg lærer det på min måte". Dette kan være en konsekvens av at eleven opplever undervisningen som lite relevant og nyttig for egne yrkesplaner, eller at han mener lekser er unødvendige, og dermed demotiverende. 
På spørsmålet om hvilke yrker elevene har fått erfaring med $i$ YFF var hensikten å få et innblikk i om elevene kan fordype seg i selvvalgt yrke, og hvordan de som var usikre på sitt yrkesvalg fikk kjennskap til yrkene i utdanningsprogrammet. På bakgrunn av disse svarene utkrystalliserte det seg noen kvalitative kategorier. Dersom eleven for eksempel oppgav navn på mange yrker og/eller skrev mange som svar, ble disse svarene lagt i kategorien mange ulike yrker. Hvis eleven svarte for eksempel "måtte styrke karakteren i fellesfag og har derfor jobba med det", "eg har gjort det eg fikk beskjed om" eller "det lareren bestemte", ble svaret plassert under kategorien lærerstyrt. Kolonnen lærerstyrt og kolonnen med mange ulike yrker kan også ses i sammenheng. Når elever må innom mange ulike yrker, kan det også oppleves som lærerstyrt. I kategorien egen yrkesplan/interesse ble svar som for eksempel "eg jobba med det yrket eg var interessert $i$, hadde lyst til, det eg syns er kjekt" og lignende plassert.

Svarene ble sett i forhold til hvilke yrker elevene eventuelt hadde bestemt seg for å utdanne seg til. Målet var å finne ut om det var deres valg som lå til grunn for denne yrkeserfaringen eller ikke. På TIP og EL har henholdsvis $8 \%$ og 6\% fått velge bedrifter eller yrkesoppgaver knyttet til hvilket yrke de ønsker erfaring med. Kolonnen med mange ulike yrker er den som skiller seg ut med størst variasjon mellom utdanningsprogrammene. Utdanningsprogrammene som skiller seg ut her er $\mathrm{DH}$ og HO. Resultatene viser at elever ved $\mathrm{DH}$ og $\mathrm{HO}$ har jobbet med oppgaver som er relatert til flere ulike yrker, uavhengig av om elevene hadde spesifikke yrkesinteresser/yrkesplaner eller ikke. Kommentarer som "det var et roteringssystem som var bestemt på forhånd og me hadde ingen innflytelse på YFF" underbygger elevenes manglende mulighet til medvirkning i eget læringsarbeid. Kommentarer som "skulle ønske jeg hadde hatt større innflytelse på undervisningen slik at jeg fikk fordype meg $i$ det jeg har lyst å utdanne meg til" indikerer at elevens muligheter til å velge yrke i faget YFF kan være begrenset, og at handlingsrommet i forskrift for Yrkesfaglig fordypning ikke utnyttes for å sikre at elevenes læringsbehov kan ivaretas. Vi spurte elevene om hvilke produkter/arbeidsoppgaver de har arbeidet med gjennom skoleåret for å finne ut om arbeidsoppgavene var relevant sett opp mot elevenes yrkesvalg/yrkesinteresser. Resultatene blir her presentert i tabellform, omgjort i prosent av hensyn til lesevennligheten.

Tabell 1. Elevenes produkter/arbeidsoppgaver i Vg1.

\begin{tabular}{|l|c|c|c|c|c|}
\hline Hvilke produkter/arbeidsoppgaver har du gjort dette skoleåret? \\
\hline UTDANNINGSPROGRAM & EL & BA & TIP & DH & HO \\
\hline $\begin{array}{l}\text { Oppgaver/produkter i tråd med } \\
\text { elevenes yrkesplan }\end{array}$ & $42 \%$ & $33 \%$ & $44 \%$ & $6 \%$ & $23 \%$ \\
\hline $\begin{array}{l}\text { Oppgaver/produkter som ikke } \\
\text { kan knyttes direkte til elevens yrkesplan }\end{array}$ & $58 \%$ & $67 \%$ & $56 \%$ & $94 \%$ & $77 \%$ \\
\hline
\end{tabular}


Tabell 1 viser hvor mange av elevene som gjennom skoleåret hadde arbeide med produkter/arbeidsoppgaver som kunne relateres til elevenes yrkesvalg. Dette spørsmålet er kun besvart av de elevene som hadde bestemt seg for yrke før eller i løpet av Vg1. Tallene er basert på vår analyse av sammenhengen mellom elevenes beskrivelser av arbeidsoppgaver og produkter de utførte i Vg1, og reelle yrkesoppgaver i det spesifikke yrket de har oppgitt som utdanningsmål. Her skiller DH seg ut ved at hele $94 \%$ av elevene beskriver arbeidsoppgaver som ikke kan relateres direkte til elevenes yrkesvalg. I tillegg til spørsmålet i Tabell 1 svarte elevene på følgende åpne spørsmål som grunnlag for vår analyse og vurdering av elevarbeidenes yrkesrelevans:

- Hvilke materialer /utstyr/verktøy etc. har du jobbet med hittil i dette skoleåret?

Svarene ble oppsummert og tolket i forhold til elevenes eventuelle yrkesplan eller yrkesinteresse. Resultatet viste at mange elever jobbet med mye forskjellig, som ikke hadde sammenheng med det yrket de hadde planlagt å utdanne seg til. Et eksempel er at kommende frisører jobbet med leire, tekstiler og papir, og svarene viser at alle elevene i samme klasse jobbet med samme materialer på samme tidspunkt, uavhengig av deres individuelle interesser og yrkesplaner.

Som grunnlag for vurdering av elevenes muligheter for medvirkning og innflytelse i opplæringen svarte de i tillegg på følgende spørsmål:

- Hvorfor har du laget disse produktene/gjort disse arbeidsoppgavene?

- Hvorfor valgte du disse materialene/dette utstyret/verktøyet?

Analyse av svarene kan tyde på at mange elever ikke hadde innflytelse på eget læringsarbeid, og at oppgavene var bestemt på forhånd av lærerne. Dette underbygges av elevens kommentarer hvor elever fra DH som hadde bestemt seg for å bli frisør, sier at de har arbeidet med strikking, sying, maling og gipsarbeid. Andre elever på DH sier de har arbeidet med å lage fuglekasse, trekniv og stol. På BA og TIP er kommentarer som "vi har laget vedkurv og jobbet med grill, hammer, smihammer og meisel". Det kommer tydelig fram at verken materialene eller arbeidsoppgavene er tilpasset ulike yrkesplaner. Elevenes beskrivelser viser at de stort sett har arbeidet med samme oppgaver, materialer og verktøy uavhengig av hvilket yrke de ville utdanne seg til. For elever som har bestemt seg eller er interessert i yrkene som de nevnte oppgavene, materialene og verktøyene passer til, er det sannsynlig av læringsarbeidet oppleves som yrkesrelevant. For elever hvor oppgavene, materialene og verktøyene ikke samsvarer med yrkesplaner eller interesser, vil læringsarbeidet sannsynligvis oppleves som verken relevant eller interessant. Totalt på alle utdanningsprogrammene viser resultatene at $29 \%$ av elevene opplever arbeidsoppgavene som relevante, mens $71 \%$ hevder at arbeidsoppgavene og materialbruken var bestemt på forhånd, og ikke hadde sammenheng med deres yrkesplan eller yrkesinteresse.

Spørsmålet Hvor stor del av tiden i programfagene og yrkesfaglig fordypning arbeider du direkte med oppgaver innen din yrkesinteresse? ble besvart av de elevene som hadde bestemt seg for yrke på det tidspunktet undersøkelsen ble gjennomført. 
Hensikten med spørsmålet var å få innblikk i hvor mye tid eleven erfarte at de fikk bruke på å lære yrket de hadde valgt, og å finne ut hvilke oppgaver de opplevde som nyttige og aktuelle for å lære yrket. Hensikten var også finne ut om det var forskjell på hvordan de erfarte nytteverdien av opplæringen i FP og i faget YFF.

Tabell 2. Tid brukt direkte på egen yrkesplan i de yrkesrettede felles programfagene (FP) og i faget Yrkesfaglig fordypning (YFF).

Hvor stor del av tiden i programfagene og yrkesfaglig fordypning arbeider $\mathrm{du}$ direkte med oppgaver innen din yrkesinteresse?

Svaralternativer: $0-25 \%, 25 \%, 50 \%, 75 \%$, mer enn $75 \%$.

\begin{tabular}{|l|c|c|c|c|c|c|c|c|c|c|}
\hline $\begin{array}{l}\text { UTDANNINGS- } \\
\text { PROGRAM }\end{array}$ & \multicolumn{2}{|c|}{ EL } & \multicolumn{2}{|c|}{ BA } & \multicolumn{2}{c|}{ TP } & \multicolumn{2}{c|}{ DH } & \multicolumn{2}{c|}{ HO } \\
\hline & FP & YFF & FP & YFF & FP & YFF & FP & YFF & FP & YFF \\
\hline $0-25 \%$ av tiden & $18 \%$ & $62 \%$ & $38 \%$ & $21 \%$ & $26 \%$ & $42 \%$ & $75 \%$ & $46 \%$ & $63 \%$ & $45 \%$ \\
\hline $50 \%$ av tiden & $31 \%$ & $14 \%$ & $31 \%$ & $12 \%$ & $34 \%$ & $23 \%$ & $10 \%$ & $20 \%$ & $11 \%$ & $24 \%$ \\
\hline $75-100 \%$ av tiden & $51 \%$ & $24 \%$ & $31 \%$ & $67 \%$ & $40 \%$ & $35 \%$ & $15 \%$ & $34 \%$ & $26 \%$ & $31 \%$ \\
\hline
\end{tabular}

Svarene i denne tabellen er basert på valg av svaralternativer som forteller hvor stor andel av tiden, i de yrkesrettede fagene gjennom YFF og de FP, elevene erfarte å jobbe med oppgaver som var knyttet til deres yrkesplan eller yrkesinteresser. Spørsmålet hadde fem svaralternativer: under $25 \%, 25 \%, 50 \%$, $75 \%$, over $75 \%$. I tabellen er de to første og de to siste svaralternativene slått sammen til henholdsvis $0-25 \%$ og $75-100 \%$ av hensyn til lesevennlighet. På bakgrunn av svarene i tabell 1 og innledende spørsmål fikk vi en indikasjon på forholdet mellom elevens erfaring av undervisningen og dens yrkesrelevans i forhold til egen yrkesinteresse i YFF og FP. Resultatene viser at elevene på EL erfarer at de får arbeide mer med oppgaver som passer til deres yrkesplaner i felles programfag enn hva de giør i Yrkesfaglig fordypning. På DH og HO arbeider elevene lite i henhold til interesser og egen yrkesplan både i felles programfag og i Yrkesfaglig fordypning. Resultatene viser samtidig at elevene i disse utdanningsprogrammene erfarer å arbeide mer i henhold til egne interesser og yrkesplaner i YFF enn i FP. Resultatene her er sammenfallene med forrige spørsmål som omhandlet hvilke arbeidsoppgaver og materialer elevene arbeidet med. Det går her fram at mange elever opplever at oppgavene, materialene og verktøyene ikke samsvarer med yrket de har valgt eller er interessert i. På DH sier for eksempel 31 av 42 elever (75\%) at de i FP arbeider mellom 0-25\% direkte med oppgaver innen deres 
interessefelt, kun 6 elever sier de har fått arbeidet mellom 75-100\% av tiden med egne interessefelt. Disse elevene hadde bestemt seg for å utdanne seg til frisører, som er det største lærefaget i utdanningsprogrammet.

\section{Bruken av handlingsrommet for en yrkesrelevant opplæring}

Når det gjelder problemstillingen om i hvilken grad handlingsrommet i læreplanene blir brukt for å sikre en yrkesrelevant opplæring for elever med ulike yrkesinteresser, viser resultatene at innflytelse på eget læringsarbeid er sentralt. Dette er i tråd med Ryan og Deci's (2017, s. 10) tanker om selvbestemmelse i utviklingen av motivasjon for læring. Utsagn som "skulle gjerne vært med på å velge oppgaver litt selv fra egen interesse, men det meste er bestemt allerede og vi fär sjelden være med a bestemme hoordan vi vil jobbe eller hoilke metoder som passer oss best" kan tyde på at graden av medvirkning og innflytelse på eget læringsarbeid oppleves som liten for elevene. Kember hevder at dersom læring skal oppleves relevant og gi mening, må det skapes en læringskontekst som preges av demokratisk diskusjon og koherens mellom undervisning og den reelle verden, som her betyr elevens livsverden (Kember et al., 2008). Ser vi på Ryan og Deci’s (2017, s. 239) selvbestemmelsesteori, som hevder at grunnleggende behov som tilhørighet, kompetanse og autonomi er sentralt for at eleven skal oppleve indre motivasjon, er kommunikasjon i et demokratisk og autonomt utdanningsmiljø avgjørende. Sett i forhold til utsagnet over kan det forstås som at eleven ikke blir tatt med i diskusjon omkring innhold i opplæringen. Dette er interessant i forhold til internasjonale studier som peker på læreres uavhengighet i forhold til arbeidslivets behov for kompetanse (Andersson, 2019; Robson, Bailey \& Larkin, 2004).

For å få et innblikk i hvor mye eleven arbeider med oppgaver som samsvarer med egen yrkesplan eller yrkesinteresser, har vi undersøkt hvor mye tid eleven har hatt til disposisjon for egne valg av læringsoppgaver tilknyttet egne yrkesinteresser i FP og YFF. Dataene viser at en svært høy andel av elevene i lange perioder ikke får arbeide etter egen yrkesplan og egne interesser. Dette indikerer at handlingsrommet $\mathrm{i}$ læreplanene i liten grad blir benyttet for å tilrettelegge for en yrkesrelevant opplæring. Produktene og oppgavene elevene arbeider med viser at elevene i samme klasse i all hovedsak arbeider med det samme til samme tid og at arbeidsoppgaver, materialer og utstyr er forutbestemt og lærerstyrt, uavhengig av elevenes utdanningsplaner. Dette samsvarer med tidligere forskning, som viser hvilken effekt slik opplæring har for engasjement og utvikling av lærelyst (Bødker-Lund et al., 2017; Dahlback et al., 2011, 2018, 2019; Hansen \& Haaland, 2015; Hiim, 2013). Kvaliteten på skoleverkstedene spiller også en viktig rolle for om praksisen skal oppleves verdifull, og at elevene synes det er spesielt givende å arbeide med autentiske arbeidsoppgaver (Olsen, Reegård, Seland \& Skålholdt, 2015). Samme studie viser at bedriftene spiller en viktig rolle for at opplæringen skal oppleves relevant, under forutsetning av at elevene får arbeide med et yrke de er interessert i. Dette støttes av internasjonal forskning, som 
påpeker viktigheten av et tett samarbeid mellom skole og bedrift i utviklingen av en helhetlig og aktuell yrkesopplæring (Wheelahan \& Moodie, 2010, s. 22).

Det ligger i styringsdokumentene ingen begrensninger når det gjelder bruk av handlingsrommet, så lenge kompetansemålene er ramme for opplæringen. Dette tilsier at på skoler hvor utstyr og/eller verksted kan være begrensende, er det fullt mulig å involvere bedriftene eller andre relevante aktører i opplæringen. Gjeldende læreplanverk gir rom for store lokale tilpasning, noe som innebærer frihet, tillit og ansvar i større grad enn tidligere for både lærere og elever. Dette skal utfordre til kreativitet både metodisk og i tilpasning av innholdet i opplæringen (Utdannings- og forskningsdepartementet, 2004).

Resultatene fra denne undersøkelsen tyder på at elevene blir pålagt å jobbe med mange ulike yrker som utdanningsprogrammet rekrutterer til. Spørsmålet er om slike breddekunnskaper resulterer i relevant fagkompetanse og gode fagfolk som bransjen har bruk for, eller om det bidrar til demotivasjon og i verste fall frafall i Vg1 (Dahlback et al., 2011; Hansen \& Haaland, 2015; Sund, 2005). I perspektiv av Ryan og Deci (2017), hvor selvbestemmelse og autonomi er en nøkkelfaktor for drivkraft og motivasjon, bidrar sannsynligvis ikke en slik breddeundervisning, hvor elevene må lære litt om mange yrker, til å utvikle verken autonomi eller motivasjon for elever som har klare yrkesplaner. Disse elevene har behov for å få arbeide med sitt yrkesvalg og fordype seg i det. Muligens kan læring av breddekunnskap passe for elever som er usikre på yrkesvalget, og som ønsker å prøve ut ulike yrker gjennom Vg1. I denne undersøkelsen hadde over halvparten av elevene en klar yrkesplan.

Opplæringen som legger opp til at elevene skal bli litt kjent med mange yrker er ikke i tråd med de nasjonale føringene som Goodlad (1979) beskriver som den intenderte læreplanen. Her pekes det på at yrkesrelevans, tilpasset opplæring, medvirkning, demokrati og dybdelæring er viktige elementer i utviklingen av kompetente fagfolk (KD, 2016). Noen elever er kanskje mindre bevisste på nytteverdien av opplæringen, og har behov for å gjøre oppgaver knyttet til ulike yrker for å opprettholde motivasjonen for å finne ut hva de kan tenke seg som fremtidig yrke. Denne typen opplæring ivaretar kanskje disse elevenes interesser. Likevel er spørsmålet hvordan overføringsverdi og læring gjennom læringsoppgaver knyttet til andre yrker kan sikres i forhold til det spesifikke yrket eleven etterhvert velger å utdanne seg til.

På EL og BA var det en stor andel som mente de hadde nok innflytelse og medvirkning på innholdet i opplæringen. Ifølge dataene var innholdet i undervisningen hovedsaklig rettet mot tømring i BA og mot elektrikeroppgaver i EL, som da synes å ivareta de største lærefagene i utdanningsprogrammene. Det kan bety at selv om opplæringen er lærerstyrt, vil framtidige tømrere og elektrikere oppleve undervisningen som yrkesrelevant, fordi de erfarer det som nyttig for sine interesser og utdanningsplaner. Undersøkelser gjort av Aarkrog og Bang (2013) viser til at eleven må ha innflytelse på eget læringsarbeid for å sikre 
opplevelse av mening og relevans, noe som kan ses i sammenheng med at elever på EL og BA ser på tømring og elektrikeroppgaver som en del av sin fremtidige kompetanse, til tross for at de skal utdanne seg til andre yrker innen disse utdanningsprogrammene. Det motsatte synes å være tilfelle for de mindre yrkesfagene, som for eksempel murerfaget i BA og Elektroreparatør i EL. At elever som vil utdanne seg til de små yrkene ikke er så fornøyde, får lite utslag i undersøkelsen, fordi antall elever med slike yrker som utdanningsmål er få i forhold til antallet som vil bli tømrere og elektrikere.

Resultatene fra denne studien tyder på at elevene på DH og HO ikke opplever breddebasert undervisning som interessant, relevant eller nyttig. I disse utdanningsprogrammene indikerer undersøkelsen at elevene opplever begrensede muligheter for elevmedvirkning og innflytelse på eget læringsarbeid. I Yrkesfaglig fordypning viser dataene at valgene er mer lærerstyrte og breddebaserte enn $i$ felles programfag. Dette er interessant når hensikten med yrkesfaglig fordypning er at elevene skal få fordype seg i det yrket eller deler av det yrket elevene har interesse for eller ønsker å utdanne seg til (KD, 2013).

Elevene i denne undersøkelsen synes å opparbeide seg overfladisk kjennskap til mange yrker i Vg1, ikke dybdelæring som i følge KD (2016) skal vektlegges i Fagfornyingen som innføres høsten 2020. Dewey (1966) er opptatt av forholdet mellom utdanning og demokrati som en livsform og et forum for kommunikasjon mellom mennesker med ulike erfaringer. Sett i forhold til relevant yrkesopplæring kreves det ifølge Dewey (1966) en demokratisk ledelse, hvor medvirkning og involvering i eget læringsarbeid skaper engasjement og motivasjon i opplæringssammenheng. Resultatene fra denne og tidligere undersøkelser kan forstås slik at elevene ønsker å medvirke mer i eget læringsarbeid, i større grad enn i dagens yrkesopplæring (Bødtker-Lund et al., 2017; Dahlback et al., 2011; Hansen, 2017; Hiim, 2013, 2015; Hovland, 2015; Jørgensen, 2015).

Resultatene er i tråd med Ryan og Deci's teori (2017, s. 247) omkring menneskelig behov for autonomi og selvbestemmelse i egne liv som grunnlag for tilfredshet. Resultatene i undersøkelsen indikerer at den intenderte læreplanen, som her representerer de nasjonale føringene, ikke samsvarer med den erfarte læreplanen (Goodlad, 1979), som presenteres gjennom elevenes erfaringer for hvordan handlingsrommet i læreplanene blir brukt i en yrkesrelevant opplæring. Med tanke på skolens mandat, som i følge Isaksen (2015) er å utdanne gode fagarbeidere for fremtiden, viser funnene at det kan være behov for å endre dagens praksis for å sikre at også det første året blir en viktig del av fagopplæringen i alle yrkene som rekrutterer fra det samme Vg1.

Med tanke på skolens mandat, som i følge Isaksen (2015) er å utdanne gode fagarbeidere for fremtiden, viser funnene at det kan være behov for å endre dagens praksis for å sikre at også det første året blir en viktig del av fagopplæringen $i$ alle yrkene som rekrutterer fra det samme Vg1. 


\section{Oppsummering og veien videre}

At utdanningen ikke er yrkesrelevant kan resultere i at det utdannes fagfolk som ikke har den kompetansen bransjen og samfunnet har behov for. Dette kan føre til at kvaliteten på yrkesutøvelsen svekkes (Bødtker-Lund et al., 2017, s. 7). De nasjonale føringene legger til rette for medinnflytelse og yrkesrelevant opplæring for elever med ulike utdanningsmål. Dette er ifølge aktuell læringsteori svært viktige elementer i opplæringssammenheng (Dewey, 1966; Ryan \& Deci, 2017). Elevene uttrykker betydningen av yrkesrelevans, og at opplæringen må ha en klar sammenheng med egne yrkesplaner eller yrkesinteresser, selv om yrkesplaner eller yrkesinteresser kan endre seg på et senere tidspunkt. Ifølge resultatene i denne artikkelen kan det se ut som begrensningene ligger i at lærerne ikke bruker læreplanenes handlingsrom i tilstrekkelig grad. Dette kan ha sammenheng med skolene og/eller skoleeiernes rammer og betingelser, noe som ikke kommer fram i denne undersøkelsen.

Til tross for at de fleste elevene før, eller i løpet av Vg1 har bestemt seg for sine fremtidige yrker, viser undersøkelsen at mange opplever første året som ikke, eller bare delvis yrkesrelevant for veien videre. Dette støttes også av tidligere forskning på feltet (Dahlback et al., 2011, 2018; Hiim, 2013). Studien viser til et behov for en systematisk, bred og kvalitativ evaluering av muligheter og begrensninger i handlingsrommet i læreplanene som grunnlag for å konkretisere endringsbehovene i nye læreplaner som er under utvikling, og som blir gjeldene fra 2020 (KD, 2017a).

Denne studien viser at det fremdeles er mange ubesvarte spørsmål som bør følges opp i videre studier, for eksempel skolene og skoleeiernes betydning i tilrettelegging for en yrkesrelevant opplæring, og hvilke muligheter og begrensninger lærerne har for å utnytte handlingsrommet i læreplanene. Undersøkelsen er en kartlegging av elevenes erfaringer med en yrkesrelevant opplæring, men den belyser ikke muligheter den enkelte lærer har i en slik tilrettelegging. Å utnytte handlingsrommet i læreplanene krever ofte utradisjonelle undervisningsmåter og et samarbeid med andre aktører på eller utenfor skolen. For eksempel kan det samarbeides på tvers av FP og FF, med bedrifter og med ledelsen på skolen. Disse elementene kan påvirke den yrkesrelevante opplæringen, og er interessant for videre undersøkelser. Medvirkning og innflytelse påvirker læringsarbeidet og elevenes utvikling av danning, evne til kritisk tenkning og deltagelse i demokratiske fellesskaper. Dette kan også være grunnlag for videre studier, og er spesielt viktig i implementeringen av ny reform, Fagfornyingen, fra høsten 2020, hvor utvikling av slik kompetanse skal styrkes. I likhet med dagens reform vil også Fagfornyingen ha et bredt spekter av ulike yrker i ett og samme utdanningsprogram. Selv om vi ikke kan generalisere resultatene fra denne studien, vil de kunne overføres til andre utdanningsprogrammer på Vg1. 
Sett $\mathrm{i}$ et internasjonalt perspektiv finner vi likhetstrekk med den norske modellen, hvor opplæringen fordeles mellom skole og bedrift (Andersson, 2019, s. 30-37). Også andre land har satt søkelyset på lærernes breddekunnskaper i gjennomføringen av en aktuell og helhetlig yrkesutdanning (Wheelahan \& Moodie, 2010). Dette kan være interessant for videre undersøkelser i utviklingen av en yrkesrelevant opplæring.

\section{Sluttnote}

1 Åse Nedrebø Bruvik, OsloMet - Storbyuniversitetet, er hovedforfatter på artikkelen.

\section{Om forfatterne}

Åse Nedrebø Bruvik er stipendiat ved OsloMet - Storbyuniversitetet, Fakultet for lærerutdanning og internasjonale studier. Hun har lang erfaring med undervisning og veiledning ved bachelorutdanningen yrkesfaglærer i design og håndverk, Praktisk pedagogisk utdanning, arbeidsplassbasert yrkesfaglærerutdanning og yrkesfaglærerløftet. Hennes forskningsinteresser er knyttet til yrkesrelevant, kompetanse- og praksisbasert opplæring.

Grete Haaland er professor ved OsloMet - Storbyuniversitetet, Fakultet for lærerutdanning og internasjonale studier. Hun har lang erfaring med undervisning og veiledning ved masterutdanningen i Yrkespedagogikk, bachelorutdanningen yrkesfaglærer i design og håndverk, Praktisk pedagogisk utdanning, arbeidsplassbasert yrkesfaglærerutdanning og yrkesfaglærerløftet. Hennes forskningsinteresser er yrkesrelevant, kompetanse- og praksisbasert opplæring, vurdering og realkompetansevurdering. Hun har mange års erfaring med forskning innenfor fag- og yrkesopplæring, er opptatt av nettverksbygging og samarbeid universitet, skole og arbeidsliv. 
Åse Nedrebø Bruvik \& Grete Haaland

\section{Referanser}

Andersson, P. (2019). Att utbilda nästa generation i yrket: En kunskapsöversikt om och för yrkeslärare. Stockholm: Skolverket.

Billett, S. (2014). The standing of vocation education: Sources of its societal esteem and implications for its enactment. Journal of Vocational Education E Training, 66(1), 1-21.

Bødtker-Lund, D., Hansen, K.H., Haaland, G. \& Vagle, I. (2017). Endringsbehov i norsk yrkesopplæring? Elevers, lærlingers og yrkesfaglæreres erfaringer med yrkesopplæring i Vg1. Skandinavisk tidsskrift for yrker og profesjoner i utvikling, 2,1-33.

Dahlback, J., Hansen, K., Haaland, G. \& Sylte, A.L. (2011). Yrkesdidaktisk kunnskapsutvikling og implementering av nye læreplaner (KIP): Veien til yrkesrelevant opplæring fra første dag i Vg1 (Rapport og utredninger nr. 1/2001). Lillestrøm: Høgskolen i Akershus.

Dahlback, J., Olstad, H., Sylte, A.L. \& Wolden, A.C. (2018). Utfordringer og muligheter i møtepunktet mellom yrkesfaglærerutdanningen og praksis i videregående skole. Nordic Journal of Vocational Education and Training, 8(3), 57-77.

Dahlback, J., Olstad, H., Sylte, A.L. \& Wolden, A.C. (2019). Yrkesfaglig yrkeskompetanse i brede utdanningsprogram. Skandinavisk tidsskrift for yrker og profesjoner i utvikling, 4(1), 1-29.

Dahlback, J. (2019). Yrkesretting av yrkesfaglige utdanningsprogram. I K. Lyngsnes \& M. Rismark (Red.), Yrkesopplæring (s. 87-103). Oslo: Gyldendal akademiske.

Dewey, J. (1966). Democracy and education. New York: The Free Press. (1. Utg 1916)

Goodlad. J.I. (1979). Curriculum inquiry: The study of curriculum practice. New York: McGraw-Hill Book Company.

Hansen, K.H. \& Haaland, G. (2015). Utfordring i norsk yrkesopplæring. I K. Hansen, T.L. Hoel \& G. Haaland (Red.), Tett på yrkesopplæring: Yrkesrelevant, tilpasset og samfunnstjenelig? (s. 19-49). Bergen: Fagbokforlaget.

Hansen, K.H. (2017). Hva er yrkesdidaktikk i dagens yrkesopplæring i skole. Skandinavisk tidsskrift for yrker og profesjoner i utvikling, 2, 1-25.

Hiim, H. (2013). Praksisbasert yrkesutdanning: Hvordan utvikle relevant yrkesutdanning for elever og arbeidsliv? Oslo: Gyldendal akademisk.

Hiim, H. (2015). Kvalitet i yrkesutdanningen: Resultater fra et aksjonsforskningsprosjekt om yrkesforankring av innholdet i yrkesutdanningen. Norsk pedagogisk tidsskrift, 99(2), 136-148.

Hovland, K. (2015). Helt fjern opplæring. I K. Hansen, T.L. Hoel \& G. Haaland (Red.), Tett på yrkesopplæring: Yrkesrelevant, tilpasset og samfunnstjenlig? (s. 212229). Bergen: Fagbokforlaget. 
Relevant opplæring i yrkesopplæringens første år

Isaksen, T.R. (2015, 2. juni). Et yrkesfagløft for fremtiden. Hentet fra https://www.regjeringen.no/no/aktuelt/et-yrkesfagloft-for-fremtiden/id2414640/

Jørgensen, C.H. (2015). Some boys' problems in education: What is the role of VET? Journal of Vocational Education E Training, 67(1), 62-77.

Jørgensen, H-J., Olsen, O.J. \& Thunquist, D.P. (2018). Vocational education in the nordic countries: Learning from diversity. London \& New York: Routledge.

Kember, D., Ho, A. \& Hong, C. (2008). The importance of establishing relevance in motivating student learning. Active Learning in Higher Education, 9(3), 249263.

Kunnskapsdepartementet. (2006). Læreplanverket Kunnskapsløftet. Oslo: Departementet.

Kunnskapsdepartementet. (2013). På rett vei - Kvalitet og mangfold i fellesskolen. (Meld. St. 20 (2012-2013)). Oslo: Departementet.

Kunnskapsdepartementet. (2016). Fag - Fordypning - Forståelse: En fornyelse av Kunnskapsløftet. (Meld. St. 28. (2015-2016)). Oslo: Departementet.

Kunnskapsdepartementet. (2017). Overordnet del - verdier og prinsipper. Hentet fra https:/ / www.udir.no/laring-og-trivsel/lareplanverket/overordnet-del/

Kunnskapsdepartementet. (2017). Nasjonal kompetansepolitisk strategi 2017-2021. Oslo: Departementet.

Kunnskapsdepartementet. (2018, 26. juni). Fornyer innholdet $i$ skolen. Hentet fra https:// www.regjeringen.no/no/aktuelt/fornyer-innholdet-i-skolen/id2606028/

Wheelahan, L. \& Moodie, G. (2010). Equality of teaching in VET: Final report and recommendations. Melbourne: LH Martin Institute, University of Melbourne.

Malterud, K. (2017). Kvalitative forskningsmetoder for medisin og helsefag: En innføring (4 utg.). Oslo: Universitetsforlaget.

NOU 2015:8. Fremtidens skole. Oslo: Kunnskapsdepartementet.

NOU 2018:2. Fremtidige kompetansebehov. Oslo: Kunnskapsdepartementet.

Olsen, O.J., Reegård, K., Seland, I. \& Skålholdt, A. (2015). Kvalitet i fag- og yrkesopplæringen: Sluttrapport. (NIFU-rapport.nr.(14)/2015)). Hentet fra https://nifu.brage.unit.no/nifu-xmlui/handle/11250/284140

Robson, J., Bailey, B. \& Larkin, S. (2004). Adding value: Investigating the discourse of professsionalism adopted by vocational teachers in further education colleges. Journal of Education and Work, 17(2), 183-195.

Ryan, R.M. \& Deci, E.L. (2000). Intrinsic and extrinsic motivations: Classic definitions and new directions. Contemporary Educational Psychology, 25, 54-67.

Ryan, R.M. \& Deci, E.L. (2017). Self-determination theory: Basic psychological needs in motivation, development and wellness. New York: The Guilford Press.

Sund, G.H. (2005). Forskjellighet og mangfold - muligheter eller begrensninger for individ og arbeidsplass: Et aksjonsforskningsprosjekt med studier av læring $i$ daglig 
arbeid, gjennom medvirkning, demokratiske prosesser og interessedifferesiering (Doktorgradsavhandling). Roskilde: Roskilde Universitetssenter.

Utdannings- og forskningsdepartement. (2004). Kultur for læring. (St.meld.nr. 30 (2003-2004)). Hentet fra https://www.regjeringen.no/no/dokumenter/stmeld-nr-030-2003-2004-/id404433/sec1

Utdannings- og forskningsdepartementet. (2006). Kunnskapsløftet - reformen $i$ grunnskole og videregående opplæring. Oslo: Departementet.

Vibe, N., Wigum Frøseth, M., Hovdhaugen, E. \& Markussen, E. (2012). Strukturer og konjukturer: Evaluering av Kunnskapsløftet: Sluttrapport fra prosjektet «Tilbudsstruktur, gjennomføring og kompetanseoppnåelse». Oslo: NIFU.

Aarkrog, V. \& Bang, S.W. (2013). Resultater af evalueringer af Kunnskapsløftet: En syntese. Aarhus: Aarhus Universitet. 